\title{
PALABRAS DEL DR. JOSÉ IGNACIO HERNÁNDEZ CRUZ*
}

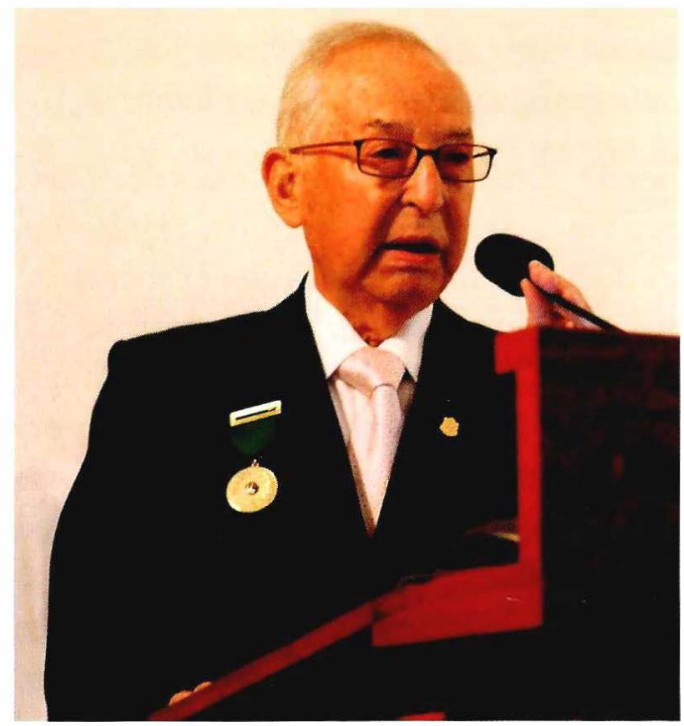

Cuan grato es recibir una llamada telefónica de manera inesperada pues es el presidente del Colegio Médico de Cundinamarca, Dr. Germán Fernández Cabrera, quien con su cuerpo directivo, tienen interés en hacer un reconocimiento a la labor médica, académica y docente que llevo desarrollando en forma ininterrumpida desde hace cinco décadas.

Cómo se enaltece y se llena de orgullo la vida de un profesor cuando sus alumnos logran posiciones sobresalientes ya sea en el campo médico, directivo, administrativo, científico o cultural. Desde luego se tiene la profunda satisfacción y orgullo de haber podido ser parte en algún momento de su formación y haber dejado una huella imborrable de mis enseñanzas. Sé cuán difícil es para ustedes dirigir en forma acertada el camino correcto del cuerpo médico y a su vez cuántas frustraciones se viven a diario.

Dr. Germán, no puedo dudar un segundo que usted permaneció por un tiempo a mi lado, usted me oyó y yo lo escuché, intercambiamos ideas, aprendimos

* Miembro Honorario de la Sociedad de Cirugía de Bogotá, Hospital de San José. Profesor Emérito de la Fundación Universitaria de Ciencias de la Salud. Bogotá DC, Colombia. cada día a hacer del acto médico una partitura magistral; aprendimos todos que no solo hay que identificarse con la enfermedad diagnosticada sino con la persona misma en su dolor, en sus esperanzas, en sus ambiciones, en sus deseos, en sus proyectos y su razón de ser y estar en este mundo.

Es a todas luces un error que se ha cometido con los alumnos el deshumanizarlos y hacer caso omiso de la persona como ser pensante que siente, que ama, con sus alegrías y sufrimientos; yo desde mi vida docente y académica he propugnado porque esta dicotomía no debe existir ni profundizarse.

Cómo agradezco esta honrosa distinción que como docente y académico ustedes me van a otorgar haciendo resaltar el valor de llevar una vida ética. Dr. Germán, quiero decir por último que me embarga el regocijo espiritual, mental e intelectual de haber cumplido con una labor abnegada.

El Dr. Chepe Hernández, como todos me conocen, goza con los triunfos de todos los que han sido mis alumnos, ahora compañeros y amigos. Gracias

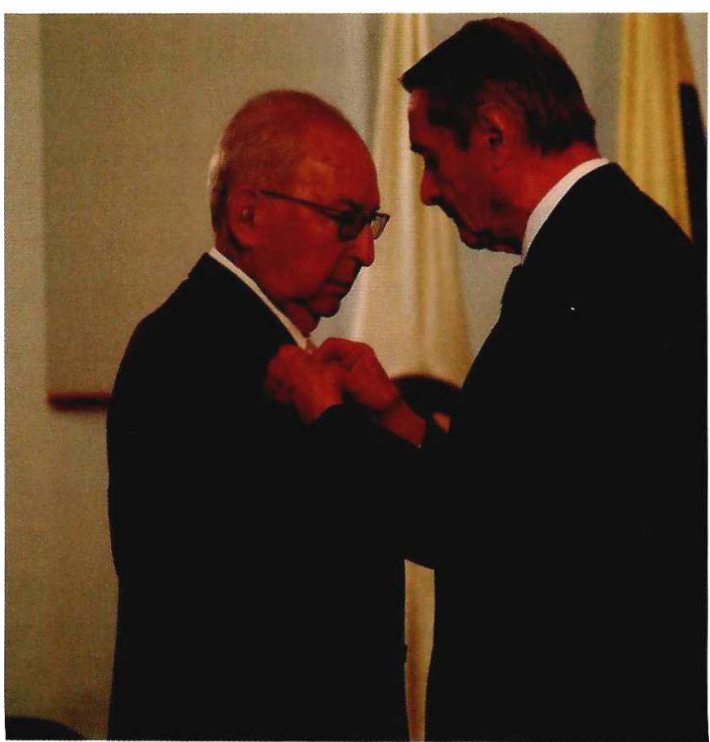

